\title{
Back on the streets
}

\section{Paris}

THE reform of education has been the national priority for the French socialist government since the 1988 elections, but the failure to bring about speedy change is provoking protests that seriously challenge the leadership. The problem, which last week produced ugly scenes as hooligans 'pirated' demonstrations by thousands of high-school pupils, is that the government's ambitious reforms are longterm while the problems of education are immediate.

The education minister, Lionel Jospin, has had his hands full since the new term began in October. University reforms proposed in an emergency plan last year involve building much-needed new teaching facilities, creating 1,500 new lecturerresearcher posts, increasing the number of school-leavers who get university places, raising postgraduate grants and doubling the number of $\mathrm{PhDs}$ within four or five years. But these reforms will take time to take effect. More than 200,000 square metres of new buildings have been opened, but student intake has increased by only 8 per cent, and there are not enough takers for the new lectureships. Students found themselves faced with much the same overcrowded lecture theatres as last year.

In 1986, under the previous Chirac government, university students took to the streets to protest against unpopular university reforms. Last week, for the first time, it was the turn of lycée pupils. More than 250,000 from all over France marched from Bastille to the Champs Elysées two days in succession, protesting that reforms were proceeding too slowly. High on their list of priorities are urgent improvements to dilapidated school buildings, more teachers and a return to order. Suburban schools around Paris are frequent targets for gang violence. Ironically, the same gangs took advantage of the demonstrations last week to pillage shops and pelt the security forces, who were under orders not to retaliate.

With a new form of taxation being pushed through parliament, the wave of unrest has taken the spotlight off Jospin and onto the Prime Minister, Michel Rocard. President Mitterrand is now thought to want to dump Rocard. Last week, he sided with the lycée pupils and told Rocard to "do something". Although Rocard immediately found an extra FF4,000 million ( $\$ 800$ million) for secondary education, this will increase the budget deficit.

Profiting from this mid-term confusion, the opposition challenged the leadership with a vote of no confidence on 19 November, but Rocard and his government survived.

Peter Coles BRAZIL

\section{Last hope for Atlantic forest?}

\section{Paris \& São Paolo}

IN what may be the last chance to save Brazil's Mata Atlantica coastal rain forest from disappearing, the Brazilian Institute for the Environment and Renewable Natural Resources (IBAMA) wants to turn part of it into a world conservation area. Tania Munhoz, president of IBAMA, was in Paris last week to present the scheme as a candidate for the United Nations Educational, Scientific and Cultural Organisation (UNESCO) Man and Biosphere (MAB) programme. MAB was holding its eleventh international coordinating council meeting at UNESCO's Paris headquarters.

So far, MAB has helped to set up 285 such 'biosphere reserves' in 72 countries. Once stretching over 850,000 square kilometres ( 10 per cent of the country), the forest has been reduced to about 3 per cent of its former size. Gnawed into by the urban sprawl of cities including Rio de Janeiro and São Paolo, and threatened by fires that spread from neighbouring farm land, the Mata Atlantica has become the second most endangered forest in the world after the rain forest of Madagascar.

IBAMA wants to designate two zones of the Mata Atlantica as MAB biosphere reserves. One is a 3,500 hectare complex - mostly tropical rain forest - around Rio de Janeiro, including the Tijuca national park and the 137 hectare botanical gardens. The second zone is on the border between the states of São Paolo and Paraná and comprises 22 existing conservation areas. Primates, including the rare lion tamarin, armadillos, several species of endangered birds and new-world cats live in the coastal forest.

Munhoz says that designation of the area as a MAB biosphere reserve will give the regions "a chance of being better conserved and will accelerate the process of protecting the ecosystem". There is little direct financial benefit to be gained from inclusion within MAB. The whole programme receives only $\$ 1.1$ million from UNESCO's budget, topped by a further $\$ 6$ million from 'extra-budgetary' sources. But IBAMA has been awarded a grant of $\$ 20$ million over three years from the World Bank for the Mata Atlantica project and already plans to spend 2,000 million cruzeiros this year on conservation work in the forest.

Peter Coles \& Ricardo Bonalume

\section{Texas votes for evolution}

\section{Boston}

STUDENTS at Texas public elementary and high schools will now use biology textbooks that teach the theory of evolution unimpeded by creationist views, thanks to a recent vote by the state's Board of Education. The board's approval of new texts for grades 1-12 will determine the choice of textbooks for the next six years and marks an important watershed for the teaching of evolution in public schools in the United States.

Until now, proponents of creationism in Texas have successfully limited coverage of evolution in biology textbooks, favouring instead a view of human origins based on a literal interpretation of the Bible. Because Texas is one of the largest centralized purchasers of textbooks in the United States, its selection process has influenced publishers and, in turn, science curricula throughout the United States.

The board's move to approve new textbooks follows the decision it made last year to require that explanation of the theory of evolution be incorporated into biology textbooks. Previously creationists had succeeded in limiting description of the theory in many of the state's schoolbooks or had required that it be taught only in conjunction with competing creationist views.

Many opponents of creationism, such as Thomas Jukes, a biophysicist at the University of California at Berkeley, hailed the news as the culmination of "a long hard fight" on the part of many participants to "try to make people in

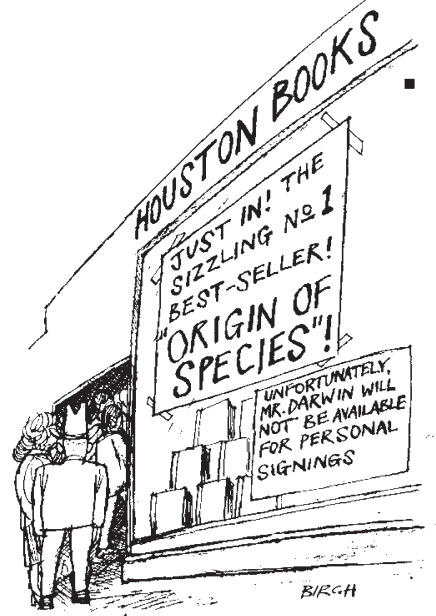

Texas realize that evolution exists". Jukes's colleague, biologist Kevin Padian, agreed, but cautioned that the threat of pseudoscientific views encroaching on science curricula is still very real. Padian urges fellow biologists and other researchers to play a greater part in the way science is taught at the elementary and highschool levels.

Seth Shulman 